\title{
Pancreatic Ascites in a Cirrhotic Patient, a Case Report
}

\section{Renata Gizani de Moura Leite, Anna Paula Mendanha da Silva Aureliano, Sara Cardoso Paes Rose, Luana Dantas Barbosa and Liliana Sampaio Costa Mendes*}

Gastroenterology Service, Federal District Base Hospital Institute, Brasília - DF, Brazil

*Corresponding Author: Liliana Sampaio Costa Mendes, Gastroenterology Service, Federal District Base Hospital Institute, Brasília - DF, Brazil.
Received: August 16, 2021

Published: August 30, 2021

(C) All rights are reserved by Liliana Sampaio

Costa Mendes., et al.

\begin{abstract}
Pancreatic ascites (PA) is a rare cause of ascites and usually appears as consequence of chronic pancreatitis. It results from an excess of exudative intraperitoneal fluid, rich in amylase and proteins, commonly originated from a pseudocyst or pancreatic duct disruption. Patients typically present mild abdominal pain, hyporexia, and sense of fullness. The diagnosis is characterized by high levels of amylase (above $1000 \mathrm{U} / \mathrm{L}$ ), proteins (above $3 \mathrm{~g} / \mathrm{dl}$ ) and low serum ascites albumin gradient $-\mathrm{SAAG}(<1.1 \mathrm{~g} / \mathrm{dl}$ ) at the ascitic fluid. The objective of this study is to report a case of a cirrhotic patient with the diagnosis of pancreatic ascites and discuss it laboratory and imaging findings, as well the main causes and treatments for this case. PA is a rare entity and either more, when occur in a cirrhotic patient. The management of cirrhotic ascites is different when there is PA. The clinicians should be aware of this possibility. Keywords: Ascites; Pancreatic Fistula; Chronic Pancreatitis; Liver Cirrhosis; Chronic Pancreatitis
\end{abstract}

\section{Abbreviations}

PA: Pancreatic Ascites; ERCP: Retrograde Cholangiopancreatography

\section{Introduction}

Ascites is a complication usually attributed to liver cirrhosis and the other etiologies are many times neglected [1]. Pancreatic ascites (PA) was first described in the literature at 1953 by Smith [2]. At this time, the prevalence was approximately $1 \%$, becoming a rare cause of ascites. It presents as excess of exudative intraperitoneal fluid which is rich in amylase and proteins, originated from the rupture of a pseudocyst or pancreatic duct [4].

PA is more prevalent in males (at the proportion of 3:1) and at the age from 20 to 50 years [3]. Patients with pancreatic ascites typically present symptoms of mild abdominal pain, hyporexia and sense of fullness. A history of chronic pancreatitis is common and also a previous episode of acute pancreatitis or new-onset ascites. However, these symptoms may be absent in alcohol use disorders and the diagnosis may be falsely attributed to liver cirrhosis [5].

Beside a detailed anamnesis and physical examination, the laboratory analysis of the ascitic fluid is essential to determine the etiology of ascites. The diagnosis of PA is characterized by high levels of amylase (generally above 1,000 IU/L) and proteins (above $3 \mathrm{~g} / \mathrm{dl}$ ). The serum albumin ascites gradient (SAAG) is less than $1.1 \mathrm{~g} / \mathrm{dl}$ [3].

The therapeutic is controversial. As a rare entity, there are few studies defining a better approach of PA [5]. The treatment can be divided in medical and interventionist therapy. The medical therapy includes withholding oral feedings, total parenteral nutrition, paracentesis and administering a splenic vasoconstrictor, like octreotide. The interventional therapy consists of endoscopic or surgical approach, offered to those who not improve with medical treatment [6]. 
The aim of this paper is to describe the evolution of a case of pancreatic ascites in a cirrhotic patient of our hospital and discuss about our diagnosis and therapeutic approach. In this way, we contribute for a better understanding of this infrequent complication in the literature.

\section{Case Report}

C.W.S.R, 44 years old, male, have history of 31 years of chronic alcoholism, with daily consumption of approximately $330 \mathrm{~g}$ of alcohol/day, in addition to abuse of illicit drugs.

In November 2020, after an episode of alcohol abuse, he presented symptoms of malaise, weakness, dizziness, and dyspnea, associated to increased abdominal volume, and was taken to an emergency room. On physical examination, he was ill appearing, pale $(1+/ 4+)$, with tachypnea and diminished breath sounds in the lung bases bilaterally. There were no signs of cyanosis or jaundice. An abdominal examination revealed marked generalized abdominal tenderness, with clinical signs of ascites and the presence of collateral circulation (Figure 1). He also presented edema of lower limbs $(4+/ 4+)$ and upper limbs $(3+/ 4+)$. Other systemic examinations were not significant.

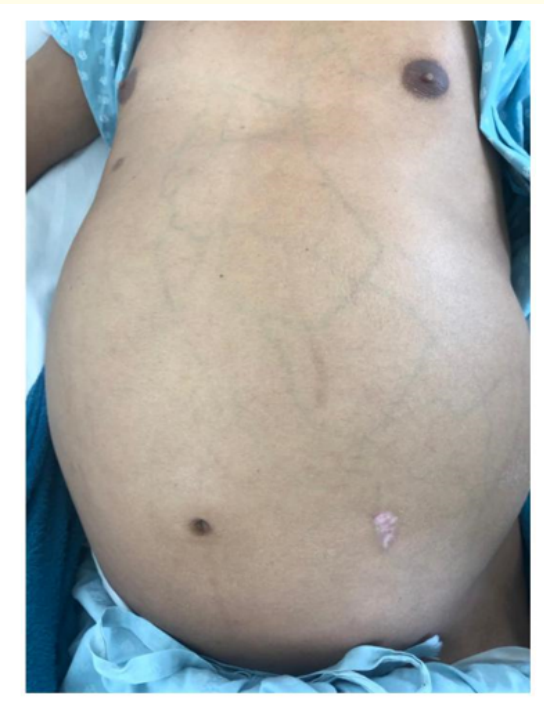

Figure 1: Patient abdomen at admission at hospital. It can be noticed an ascitc abdomen, with collateral circulation (font: Renata Gizani de Moura Leite, Anna Paula Mendanha da Silva Aureliano, Sara Cardoso Paes Rose, Luana Dantas Barbosa, Liliana Sampaio Costa Mendes).
After initial clinical stabilization measures, he was submitted to laboratory tests (Table 1) and abdominal contrast-enhanced computed tomography (CT), which revealed massive ascites, signs of chronic pancreatitis complicated by pseudocysts and chronic liver disease with portal hypertension. An abdominal doppler ultrasound identified signs of portal hypertension and stigmata of chronic liver disease.

\begin{tabular}{|l|c|c|c|}
\hline Laboratory exam & $\mathbf{1 1 / 1 1 / 2 0 2 0}$ & $\mathbf{2 1 / 1 1 / 2 0 2 0}$ & $\mathbf{0 1 / 1 2 / 2 0 2 0}$ \\
\hline Amylase & $407 \mathrm{U} / \mathrm{L}$ & $408 \mathrm{U} / \mathrm{L}$ & $163 \mathrm{U} / \mathrm{L}$ \\
\hline $\begin{array}{l}\text { Aspartate } \\
\text { transaminase (ALT) }\end{array}$ & $193 \mathrm{U} / \mathrm{L}$ & $32 \mathrm{U} / \mathrm{L}$ & $26 \mathrm{U} / \mathrm{L}$ \\
\hline $\begin{array}{l}\text { Alanine } \\
\text { transaminase (AST) }\end{array}$ & $45 \mathrm{U} / \mathrm{L}$ & $11 \mathrm{U} / \mathrm{L}$ & $8 \mathrm{U} / \mathrm{L}$ \\
\hline $\begin{array}{l}\text { Gamma-glutamyl } \\
\text { transferase (GGT) }\end{array}$ & $896 \mathrm{U} / \mathrm{L}$ & $216 \mathrm{U} / \mathrm{L}$ & $180 \mathrm{U} / \mathrm{L}$ \\
\hline $\begin{array}{l}\text { Serum alkaline } \\
\text { phosphatase }\end{array}$ & $645 \mathrm{U} / \mathrm{L}$ & $257 \mathrm{U} / \mathrm{L}$ & $247 \mathrm{U} / \mathrm{L}$ \\
\hline $\begin{array}{l}\text { Total Bilirubin } \\
\text { Direct Bilirubin }\end{array}$ & $4,05 \mathrm{mg} / \mathrm{dL}$ & $1,74 \mathrm{mg} / \mathrm{dL}$ & $0,66 \mathrm{mg} / \mathrm{dL}$ \\
\hline Indirect Bilirubin & $0,47 \mathrm{mg} / \mathrm{dL}$ & $0,8 \mathrm{mg} / \mathrm{dL}$ & $0,33 \mathrm{mg} / \mathrm{dL}$ \\
\hline Blood urea nitrogen & $16 \mathrm{mg} / \mathrm{dL}$ & $86 \mathrm{mg} / \mathrm{dL}$ & $16 \mathrm{mg} / \mathrm{dL}$ \\
\hline Creatinine & $0,91 \mathrm{mg} / \mathrm{dL}$ & $2,28 \mathrm{mg} / \mathrm{dL}$ & $0,73 \mathrm{mg} / \mathrm{dL}$ \\
\hline
\end{tabular}

Table 1: Result of laboratory findings of the case, related to the date.

Several paracentesis were performed, due the rapid increase of abdominal volume associated with symptoms of pain and dyspnea. At ascitic fluid analysis, it was noticed a persistently high value of the amylase enzyme (Table 2) in addition to high level of red blood cells, probably due to puncture accidents during the procedure, and the measure of polymorphonuclear (PMN) cells above 250 cells/mm3, configuring spontaneous bacterial peritonitis (SBP), either after reduction of PMN according with proportion of red blood cells in ascites and was treated with ceftriaxone at a dose of $2 \mathrm{~g} /$ day. Although the serum albumin ascites gradient (SAAG) in the case was greater than $1.1 \mathrm{~g} / \mathrm{dl}$, suggesting ascites due portal hypertension, the persistent elevated amylase raised the hypothesis of pancreatic ascites. This diagnosis was confirmed by magnetic resonance cholangiopancreatography (MRCP) that identified a pancreatic fistula. The clinical management of ascites was based in relief paracentesis, associated with parenteral diet and administration of octreotide at a dose of $100 \mathrm{mg}$ every 8 hours, resulting in a decreased abdominal volume and increased time interval between abdominal fluid drainages. 


\begin{tabular}{|l|c|c|c|}
\hline Ascitic fluid & $\mathbf{2 1 / 1 1 / 2 0 2 0}$ & $\mathbf{2 3 / 1 1 / 2 0 2 0}$ & $\mathbf{2 5 / 1 1 / 2 0 2 0}$ \\
\hline Color & Brown & Brown & Brown \\
\hline Aspect & Turbid & Turbid & Turbid \\
\hline White cell & - & $980 / \mathrm{mm}^{2}$ & $390 / \mathrm{mm}^{2}$ \\
\hline Red cell & - & $4200 / \mathrm{mm}^{2}$ & $2250 / \mathrm{mm}^{2}$ \\
\hline Granulocytes & - & $63 \%$ & $45 \%$ \\
\hline Total protein & $1,9 \mathrm{~g} / \mathrm{dL}$ & $1,8 \mathrm{~g} / \mathrm{dL}$ & $2,1 \mathrm{~g} / \mathrm{dL}$ \\
\hline Glucose & - & $75 \mathrm{mg} / \mathrm{dL}$ & $98 \mathrm{mg} / \mathrm{dL}$ \\
\hline $\begin{array}{l}\text { Lactate } \\
\text { dehydrogenase }\end{array}$ & $742 \mathrm{U} / \mathrm{L}$ & $624 \mathrm{U} / \mathrm{L}$ & $600 \mathrm{U} / \mathrm{L}$ \\
\hline Amylase & $1712 \mathrm{U} / \mathrm{L}$ & $3282 \mathrm{U} / \mathrm{L}$ & $2218 \mathrm{U} / \mathrm{L}$ \\
\hline $\begin{array}{l}\text { Serum-ascites } \\
\text { albumin gradient }\end{array}$ & 1,79 & 1,98 & 1,26 \\
\hline Culture & Negative & Negative & Negative \\
\hline
\end{tabular}

Table 2: Results of laboratory analysis of ascitic fluid of the patient.

Other exams were needed to assess the evolution of the disease. An upper digestive endoscopy (EDA) showed no esophageal varices and an enanthematous bulbar duodenitis. A transthoracic echocardiography revealed preserved biventricular systolic function, with an ejection fraction of 58\% and bilateral pleural effusion.

During hospitalization, the patient developed hepatic encephalopathy with altered level of consciousness, and aspiration pneumonia. He became to acute respiratory failure and septic shock. Orotracheal intubation, use of vasoactive drugs and admission to the Intensive Care Unit (ICU) was required. At end, the patient developed a cardiopulmonary arrest (CPA) without return to spontaneous circulation, despite all measures. He died one month after the onset of his condition and the interventional therapy was not possible.

\section{Discussion}

The pancreatic ascites it is a rare condition, with approximately 250 cases reported in the literature. Its therapeutic is still controversial in many aspects, and more studies are needed for develop a better approach for this disease. For this reason, a better knowledge of this clinical entity is increasingly necessary for its correct diagnosis and a better therapeutic approach of this condition.

The case described in this paper reports the difficulty of attributed cases of pancreatic ascites in a chronic liver patient with portal hypertension. PA has higher prevalence among men aged 20 to 50 years [3]. The chronic pancreatitis due alcoholic disease is the most common etiology and corresponds with approximately $66.2 \%$ of causes [7]. Pancreatic trauma, cystic duplication of the biliopancreatic ducts, ductal lithiasis and ampular stenosis are the other etiologies of PA [7].

PA can appear during any phase of chronic pancreatitis, however, it is more common in the initial phases, when there is a smaller amount of fibrosis and secretory capacity of the gland are preserved. This patient had signs of cirrhosis and SAAG > 1.1 and the abdominal pain was initially attributed of large ascites in a chronic liver patient. There were no signs of enlargement of pancreas but pancreatic fistulae was documented.

The pathophysiology of ascites is related to the release of pancreatic enzymes in the abdominal cavity, leading to irritation of the peritoneum. The extravasation of pancreatic secretion in the abdominal cavity occurs, most of the time, due to the rupture of a pancreatic pseudocyst $[7,8]$. Secondly, it can occur due the presence of a fistula in the pancreatic duct or due to its traumatic rupture. In about 10 to $20 \%$ of cases, the location of the extravasation is not identified [9].

The most common symptoms of PA are abdominal pain, weight loss and progressive abdominal distension due to ascites, that can be associated with pleural effusion. Our patient had all of these signs and symptoms.

For the diagnosis of PA, laboratory findings and analysis of ascitic fluid are essential. The ascitic fluid presented high values of amylase and proteins. Despite of an SAAG > 1.1 and the SBP treated, there were no explication for the elevated amylase in ascitic fluid in a cirrhotic patient, so the diagnostic of PA was made. The literature does not show cases of these two situations in the same patient but the clinicians should attempt to this possibility to properly manage.

Medical treatment consists of withholding oral feedings, parenteral nutrition, paracentesis, and somatostatin analogues such as octreotide. Although total parenteral nutrition is not useful alone, it should be considered as an adjunctive therapy [1]. The objective of treatment is to reduce the pancreatic secretion and ascites, and with this, close the pancreatic fistula [10]. The medical therapy is preferred in most cases, despite it has a high failure rate when not associated with other therapeutic methods, such as surgical or endoscopic treatment [8]. 
The use of octreotide in these patients can be controversial. Goméz-Cerezo., et al. [7], in a review of PA cases, did not identify significant benefit with the use this drug. However, this review included a small sample of patients that received the medication and they were treated with different doses and routes of administration, which could have led these inconclusive results. Goméz-Cerezo., et al. [7] also established that the only surgical and endoscopic treatments were beneficial in the management of pancreatic ascites. However, other authors recommend start with medical treatment for 2 to 3 weeks and in case of failure the interventional treatment should be considered [11].

Endoscopic treatment consists of performing retrograde cholangiopancreatography (ERCP) to determine the site of leakage in pancreatic duct in order to stenting and provide the right drainage of pancreatic secretion [11].

In our case, it was decided to start with medical treatment. The performance of ERCP for placement of the prosthesis was reserved for a second moment. However, the patient evolved unfavorably due to complications related to liver cirrhosis, before the procedure could be done.

The outcome of our case was different than what I found on other reports in literature. The majority of patients presents clinical good prognosis with both medical treatment and endoscopic treatment. The presence of chronic liver disease and its complications had contributed with negative outcome in our case, and so it is not possible to correlate with other cases in the literature.

\section{Conclusion}

PA is a rare entity and either more, when occur in a cirrhotic patient. The management of cirrhotic ascites is different when there is PA and the clinicians should be aware of this possibility.

\section{Conflict of Interest}

There are no conflicts of interest.

\section{Bibliography}

1. Junior DRA., et al. "Ascite: estado da arte baseado em evidências". Revista da Associacao Medica Brasileira 55.4 (2009): 489496.

2. Smith EB. "Hemorrhagic ascites and hemothorax associated with benign pancreatic disease". Archives of Surgery 67.1 (1953): 52-56.
3. Fernández-Cruz L., et al. "Pancreatic ascites". Hepatogastroenterology 40.2 (1993): 150-154.

4. Bhandari R., et al. "Pancreatic ascites managed with a conservative approach: a case report". Journal of Medical Case Reports 14.1 (2020): 154.

5. Martins Junior EV., et al. "Pancreatic ascites - case report". Revista da Sociedade Brasileira de Clínica Médica 1.1 (2003): 2628.

6. Carrier P., et al. "L'ascite non liée à lacirrhose: physiopathologie, diagnostic et étiologies [Non-cirrhotic ascites: pathophysiology, diagnosisandetiology]". La Revue de Médecine Interne 35.6 (2014): 365-371.

7. Kanneganti K., et al. "Successful Management of Pancreatic Ascites with both Conservative Management and Pancreatic Duct Stenting". Gastroenterology Research 2.4 (2009): 245-247.

8. Gómez-Cerezo J., et al. "Pancreatic ascites: study of therapeutic options by analysis of case reports and case series between the years 1975 and 2000". The American Journal of Gastroenterology 98.3 (2003): 568-577.

9. Parekh D and Segal I. "Pancreatic ascites and effusion. Risk factors for failure of conservative therapy and the role of octreotide". The Archives of Surgery 127.2 (1992): 707-712.

10. Moosa AR. "Surgical treatment of chronic pancretitis: an overview". British Journal of Surgery 74.8 (1987): 661-667.

11. Munshi IA., et al. "Resolution of refractory pancreatic ascites after continuous infusion of octreotide acetate". International Journal of Pancreatology 17.2 (1995): 203-206.

\section{Volume 4 Issue 9 September 2021 (C) All rights are reserved by Liliana Sampaio Costa Mendes., et al.}

